\title{
INTENSIVE TOWN MILK PRODUCTION
}

\author{
T. R. ELLETT \\ Farmer, Mangere
}

IhUMatao farms comprised a town supply farm at Mangers (No. 2 farm) until six years ago, when a sheep farm situated $32 \mathrm{~km}$ away at Karaka was purchased (No. 1 Farm). For a number of reasons the sheep farm was set up for town supply, the quota transferred, and the two farms integrated and managed as one unit. No. 1 Farm is given over entirely to town milk production plus the- rearing of approximately 250 calves each year to the weaning stage. No. 2 Farm at Mangere takes all cows while dry from the town supply herd, fattens cull cows, and rears heifers for sale, herd replacements and dairy boef bulls. The two farms are self-contained so far as stock are concerned. No stock are ever purchased. Approximately 250 head of cattle are sold each year. No. 1 Farm has a 2050 litre quota.

No. 1 Farm is flat to undulating, with a Karaka complex scil of poor natural fertility which responds well to phosphate and potash and has approximately 80 ha in grass.

No. 2 Farm is flat to hilly: the soil is of volcanic origin, onethird being ploughable and the rest consisting of basalt outcrops and stony ground. Of high natural fertility, it requires modest dressings of phosphate and potash and has 77 ha in grass. Rainfall for both farms approximates $120 \mathrm{~mm} /$ year. In most years there is a definite dry summer period and a few light frosts in winter. Both farms have a free-draining soil and could be described as being good winter country.

\section{STOCK NUMBERS}

Stock numbers reach a peak in August each year, and at August 31, 1973, No. 1 Farm had a town supply herd of 195 , was rearing 62 calves, and had 1 bull, a total of 258. During the year approximately 245 cows and heifers actually calved down on this farm. No. 2 Farm had 38 dry cows, 41 in-calf heifers, 64 dry heifers, 41 bulls for beef, and 113 weaners of various ages and sex, a total of 303. Total stock on both farms was thus 561 . 


\section{PRODUCTION}

Production over the past seven years has been as follows:

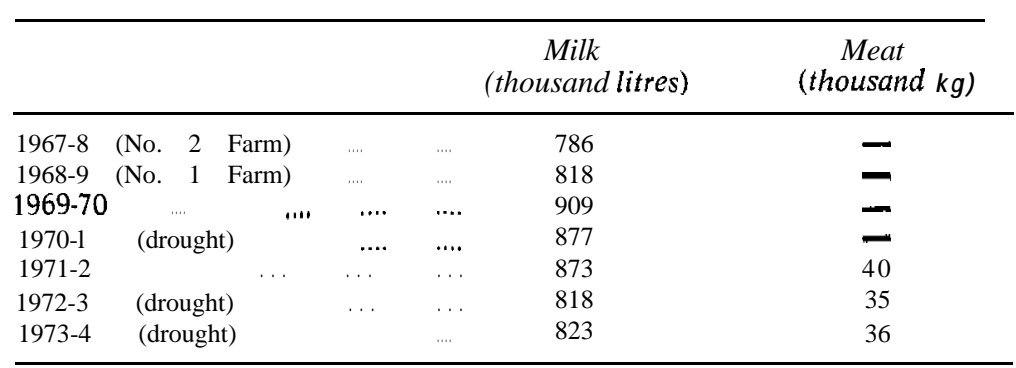

Put another way, in the year ended March 31 , 1974, No. 1 Farm produced approximately 10800 litres per hectare (or $450 \mathrm{~kg}$ butterfat) plus rearing 250 calves to approximately 12 weeks of age. No. 2 Farm produced approximately $500 \mathrm{~kg}$ of meat per hectare.

\section{TOPDRESSSING}

No. 1 Farm receives 2.5 tonnes of lime per hectare every four years plus 1 tonne of $30 \%$ potassic superphosphate in a split dressing in November and April. In addition, 10 to 12.5 tonnes of urea for winter and early spring grass are applied.

No. 2 Farm receives 2.5 tonnes of lime every 7 years, $750 \mathrm{~kg}$ $15 \%$ potassic superphosphate and 7.5 to 10 tonnes of urea in winter.

\section{LABOUR}

Three married men work permanently at No. 1 Farm and an additional mobile labour unit alternates between the two farms as circumstances dictate.

\section{BREEDING PROGRAMME}

The herd has always been herd-tested and A.B. is used all the year round. Mainly Friesian semen but sufficient Jersey semen is used to keep a reasonable solids-not-fat and butterfat level required for town supply. Calves are reared on whole milk for a few days then "Denkavit" for "approximately five weeks when they are weaned on to meal (50:50 mixture of maize and barley meal), grass and hay. They are housed for the first 3' or 4 weeks' from June to August. 


\section{PASTURES}

The original sheep pastures on No. 1 Farm (mainly ryegrass, cocksfoot and paspalum) are now being replaced after a marrowstem kale crop and/or under a grass-to-grass system with our own Mangere strain of perennial ryegrass ( $16.8 \mathrm{~kg}$ ) and $3.4 \mathrm{~kg}$ of pedigree white clover per hectare. Young grass is sprayed with 2,4-DB for weed control, especially seedling docks.

On No. 2 Farm at Mangere it was found about 18 years ago that the local ryegrass was significantly superior to the certified strains that were then available. Since that time, whenever the need for pasture renewal has arisen, our own seed has been harvested and resown. All things considered, it is my opinion that the variations of climate and soils are so great that research workers and policy makers have been wrong in continuing to attempt to breed strains of grasses that will suit all conditions from the North Cape to the Bluff. Some regional strains are called for. It is most unfortunate that it has been the farmer who has suffered from this policy, and in the South Auckland area at any rate this has been so, particularly after the introduction of Ariki ryegrass which simply does not measure up to the demands made upon it. I feel from observations already made, that the new strain, Nui, will be a big improvement - it really cannot help being so when Ariki is so poor. Nevertheless, if Grasslands Division and the Ministry of Agriculture and Fisheries persist generally in their policy of one strain for all of New Zealand to meet a particular need, then local strains are bound to appear in the effort to meet farmers' needs. In the final analysis, it is the farmers themselves who will be the judges of what suits them best. What I have said in no way belittles the great and important contributions that Grasslands Division has and is ccatinuing to make in this field. I suggest there is a case for them to go back to their drawing boards with a fresh approach to this particular problem. With all the resources they have behind them, they should be able to produce a veritable tiger of a ryegrass for our environment.

The second point I would like to make in passing relates to white clover and the role it plays in New Zealand pastures. Recently there has been some attention paid to the so-called contribution to the fertility cycle that white clover makes through its ability to fix 'atmospheric nitrogen. Coupled with more frequent recommendations from advisers to use artificial nitrogen, I fear that in the minds of an ever-increasing number of farmers there is a growing conviction that the role of white clover is not 
as important as it was thought to be. Nothing could be further from the truth, White clover is going to be the main source of nitrogen for many years to come over the great bulk of our grasslands. It is most unlikely that the price of artificial nitrogen will be such that it can be economically used in large quantities over large areas (witness the present price increase from $\$ 80$ to over $\$ 200$ per tonne within the space of a few months). Advisers, I feel, would be wise whenever suggesting the use of artificial nitrogen to stress the need for the farmer to be more careful than ever in his attention to and his subsequent management of his pastures to ensure that the white clover portion of the sward does not suffer. In fact, the use of artificial nitrogen apart, I suggest many farmers do not really understand just how important white clover is and how it can be manipulated by grazing and pasture management to keep it in an optimum balance with the grass component.

\section{WEEDS}

On No. 1 Farm gorse and blackberry have now been restricted to a few gullies and are sprayed regularly. Barley grass and California thistle have been reduced to a few small Patches which are hand-sprayed. On No. 2 Farm California thistle, blackberry and barley grass have been completely eradicated. Persistence and patience are the key words in a successful weed eradication programme.

\section{GENERAL MANAGEMENT POLICY}

With a 2050 litre quota to meet every day of the year, the town supply herd is given precedence over all else. All planning is orientated towards production per hectare rather than production per cow. In fact this also applies to meat production. In principle we aim at utilizing the maximum amount of feed grown directly as grass. Until four years ago an all-grass system was practised with relatively small amounts of silage and hay being conserved and any deficit was made up whenever necessary with purchased hay and/or meal. Two factors have been responsible for a change in this policy.

First, the rapid and widespread invasion of soldier fly and subsequent detrimental effect on production as a result of pasture damage forced No. 1 Farm into a cropping and pasture renewal programme. This has been a costly exercise but to date the only: 
course left open, short of doing nothing and watching production decline further.

Secondly, at No. 2 Farm, on light soil prone to summer droughts, it has been found more profitable to quit most surplus stock at the end of the winter and spring rather than attempt to carry them over. The resulting surplus grass is now made into hay with a consequent reduction in the amounts that have to be bought in.

We are now in such a position that, with the effects of two severe droughts and the depredations of insect pests, production has not only come to a standstill but has dropped back. Doubtless good seasons will come again but the pest problem is, I fear, going to be with us for a long time. The recent appearance of the white-fringed weevil and black beetle has added to these fears.

\section{PROBLEMS}

\section{INSECT PESTS}

There are few farmers throughout the North Island who have not had the experience, within the last two seasons, of witnessing serious pasture damage due to the depredations of such pests as soldier fly, grass grub, white-fringed weevil, or black beetle. I think it would be fair to say that the magnitude of the physical damage caused by insects and the feelings of frustration and hopelessness the situation engenders in farmers' minds are such that this is the number one problem limiting increased production at present. The pest problem is not being tackled as vigorously and effectively as it should be.

\section{Mastitis}

This is not a new problem but it can be a most worrying one at times. With the emphasis on milking a large number of cows per labour unit, less and less time is being given to mastitis control measures and, even when these are part of the milking routine, outbreaks still occur. The recent overseas interest in leucocyte counts as a further means of quality control in milk products is going to add to the dairy farmer's burden.

\section{CALF REARING}

For five years now we have wrestled with problems associated with rearing some 250 calves on an all-year-round basis. Underestimation of the labour input involved and the health problems 
encountered have been the two major errors. What problems we still have are confined to the first three weeks of the calf's life. It is my observation that permanent facilities, however elaborate, are no guarantee of success. In fact they are frequently a hazard and calf searing is an enterprise demanding a high degree of husbandry. The personal factor is most important.

\section{PRODUCTIVITY}

In conclusion, a word about increasing productivity. I am aware of the technology that would enable us to achieve, say, another 25 to $30 \%$ lift on present production levels (which are already considerably above the average for the district) but I am also bound to say that, because of the amounts of additional labour and capital required to achieve this in relation to expected returns, I will not be striving for such a goal in the present economic climate. With sizeable price increases most uncertain, with inflation rampant, costs rising dramatically, labour in extremely short supply, and the future of the town milk industry being threatened, only a fool would embark on such an undertaking. The significance of the now fashionable phrase "quality of life" has at last reached the space between the ears of the man who wears the gumboots. Today fewer and fewer men and youths like milking cows. The unending emphasis on increasing the number of cows milked per labour unit, the early nours, the drag of twice-daily milking, the ever-increasing quality standards demanded make the job less and less attractive to many, My adviser friends tell me, correctly I believe, that rather than endeavouring to farm more intensively I should simply buy more land. At a time when agriculture should be becoming more intensive, the trend is in just the 'opposite direction — towards more extensive types of farming. That this should be the situation is bad and the future does not augur well for the dairy industry.

The implications of a forty-hour week, the right of employees to refuse overtime, the introduction of the national superannua. tion scheme where the whole $8 \%$ of contributions will in practice become another additional farm cost, and a state of permanent over-employment will mean that there will have to be further massive increases in prices and a corresponding decrease in meat prices before the dairy industry will cease to decline.

Further, where one person has to invest so much capital of his own and become personally responsible for an ever-increasing mortgage burden, the likely returns are just not good enough. 
Taxation laws formulated years ago are no longer applicable to the current situation. Farmers who say moaey is not important, and that farming is a way of life, are doing the industry a disservice. There is nothing wrong with a manufacturer's way of life, believe me, or the way of life of a seaman who gets $\$ 8500$ per annum and six months' holiday; you can rest assured that by the time the farmer and farm employee get 6 months' holiday, our seaman friend will be away and running to maintain his relativity.

It is my belief that agriculture must have a new deal if it is going to continue to grow and thrive under the terms and conditions laid down by the planners of a social and economic community based on an affluent society primarily interested in the quality of life. My fear is that the whole country is going to have to pay a very big price before "agriculture gets the new deal it must have if it is going to continue to expand at a satisfactory rate. 